\title{
80. Long-term Cultivation of Cells Derived from a Xenopus laevis Tumor
}

\author{
By Makoto Asashima, Tetsuo SAsaki, and Tomoko Takuma \\ Department of Biology, Yokohama City University, \\ Seto, Kanazawa-ku, Yokohama 236 \\ (Communicated by Kiyoshi Takewaki, M. J. A., Oct. 13, 1986)
}

Among amphibian tumors, renal adenocarcinoma in Rana pipiens and papilloma in Cynops pyrrhogaster have been studied at some length. ${ }^{1)-31,10), 11)}$ However, our knowledge on tumors in other amphibians including Xenopus laevis is restricted..$^{6), 12), 15)}$

Tweedell and Williams ${ }^{16}$ ) succeeded in in vitro culture of tumor cells from Lucké renal adenocarcinoma occurring in Rana pipiens and reported the characterization of the cell lines and some nuclear transplantation experiments in these cells. ${ }^{5), 8)}$

In this paper we report a long-term cultivation of cells derived from a tumor of Xenopus laevis.

Materials and methods. Tumor of Xenopus laevis. The sarcoma-bearing specimen of Xenopus laevis used in this study was one of about 20,000 frogs reared from eggs over a period of 2 years in a pond of a dealer in Hamamatsu, Shizuoka Prefecture, Japan. This frog was found in May 1983, and then kept for nine months in a plastic aquarium $(24 \times 33 \times 10 \mathrm{~cm})$ in this laboratory at $20^{\circ} \mathrm{C}$. It was a female about $8 \mathrm{~cm}$ in length, carrying a tumor of $24 \mathrm{~mm}$ in diameter on the dorsal side.

Primary culture: After the frog was washed with running fresh water for $2 \mathrm{hrs}$, it was killed by destroying the hindbrain and pithing the spinal cord. The skin over the tumor was disinfected and cleaned with $70 \%$ ethanol, the tumor tissue was then excised under sterile conditions in a clean room.

The tumor pieces were washed several times with autoclaved phosphatebuffered saline solution (PBS) at $\mathrm{pH} 6.8$ with $1 \mathrm{~g}$ kanamycin sulphate (Meijiseika Co.)/liter, before transferring into amphibian culutre medium (ACM), 4),14) containing 50\% Leibovitz's medium (L-15 medium, Gibco Co.), $10 \%$ fetal bovine serum (Flow Labo. Co., Australia), $40 \%$ distilled water and $0.2 \mathrm{mg}$ kanamycin sulphate/ml. The pieces were further cross-sliced into small fragments (about $2 \mathrm{~mm}^{3}$ ) with two sharp scalpels. The fragments were washed with ACM in a 35-mm culture dish (Falcon 3801; Primaria Co., U.S.A.) and finally 8 or 12 fragments were placed in each of several culture flasks having a $25-\mathrm{cm}^{2}$ growth area (Falcon 3813; Primaria Co., U.S.A.), using Pasteur capillary pipettes. After incubation at $25^{\circ} \mathrm{C}$ for one hour, $5 \mathrm{ml}$ of $\mathrm{ACM}$ was added into each flask, the cap of each flask being sealed hermetically. The culture was continued at $25^{\circ} \mathrm{C}$ in an incubator (Sanyo Incubator MIR-151), the ACM being changed every 5 days.

Subculture: The cells grown out from the tumor fragments were dissociated from the bottom of culture flask with $\mathrm{Ca}-\mathrm{Mg}$-free PBS containing $0.1 \%$ trypsin (Difco 1:250) and $0.02 \%$ EDTA (Wako Dotite Co.). A three-fold volume of ACM was added to stop the action of trypsin, and aliquots of the suspension were transferred to centrifuge tubes (Falcon 2095 Tube) and centrifuged at 1,000 rpm 
for 5 min. Precipitate from each tube was resuspended in $5 \mathrm{ml}$ of ACM, recentrifuged, and the residue was resuspended in $2-5 \mathrm{ml}$ of culture medium. Aliquots of the resuspended solution were then transferred to new culture flasks. Incubation at $25^{\circ} \mathrm{C}$ for $1 \mathrm{hr}$ allowed the cells to attach to the bottom surface. The sub-culture was further continued at $25^{\circ} \mathrm{C}$, the medium being changed every 5 days.

Electron microscopy: For electron microscopy of cultured cells, cell foci stripped off with a rubber spatula were fixed in a buffered $(0.05 \mathrm{M}$ phosphate buffer, $\mathrm{pH} 7.2) 2.5 \%$ glutaraldehyde solution containing $2 \%$ paraformaldehyde and $0.1 \%$ picric acid, ${ }^{7}$ and embedded in Epon. Sections were stained with $2 \%$ uranyl acetate and lead citrate and observed with a JEM-100C electron microscope.

Results. The tumor measured $2.4 \times 2.2 \times 1.3 \mathrm{~cm}$. The waist and hind-limbs appeared normal upon external observation, although the tumor cells had infiltrated into surrounding muscles, e.g. m. glutaeus, m. rectus femoris anterior and $\mathrm{m}$. vastus medialis. The central regions of tumor cell masses were usually necrotic, the rest of the masses appearing viable histologically.

Primary culture: On about the tenth day after the start of primary culture, fibroblastic cells grew out from the blocks, sometimes followed by small grouping of neural cells and blood cell-like cells. When cultured cells formed such groups, the culture was divided into sub-cultures.

Sub-cultures: About three months after the start of sub-culture, a few melanophores containing much melanin and bearing processes became visible. After prolonged cultivation for about two and a half years, four types of cells were distinguishable by phase-contrast microscopy in a majority of culture flasks.

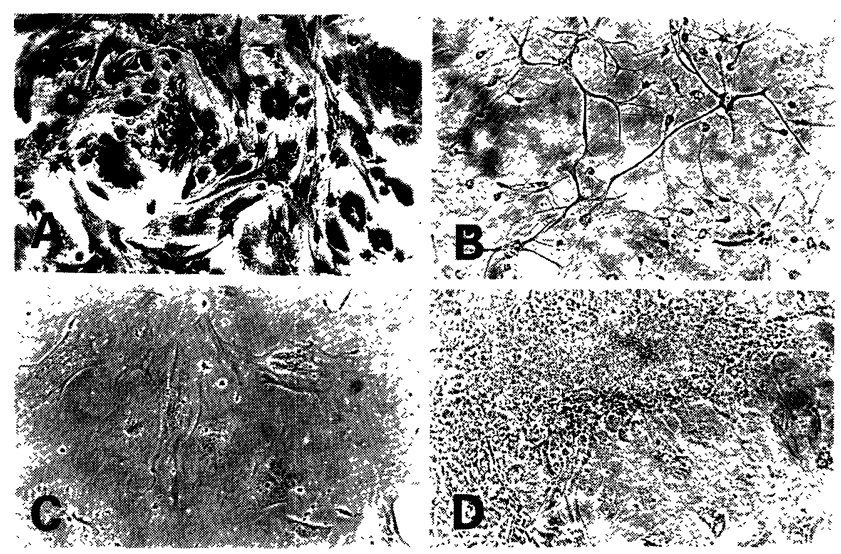

Fig. 1. Morphological profiles of four cell types derived from a Xenopus tumor mass, after cultivation over 2 years. A: Melanin-containing cells. B: Neuroid cells. C: Fibroblastic cells. D: Blood cell-like cells.

1) Melanin-containing cells: A few cells containing melanin granules, first clearly visible after about three months of sub-culture (Fig. 1A), proliferated actively and became classifiable into two groups. The first group consisted of round cells measuring about $400 \mu \mathrm{m}$ in diameter with no processes. The cells were visible to the naked eye. In the sheet of cells lining the bottom of culture 
flasks, grouped pigment cells were seen as black dots. The second group consisted of smaller cells with processes, measuring less than $100 \mu \mathrm{m}$ in diameter.

2) Neuroid cells: The cells were variable in size. Those bearing central bodies measured about $20 \mu \mathrm{m}$ in diameter and had a number of dentritic branching processes. Some neuroid cells had slender dendrites resembling axons. The cells were contact with each other at the tips of these processes (Fig. 1B). A group of these cells sometimes consisted of more than ten cells, overlapping each other. The cell diameters varied from 20 to $200 \mu \mathrm{m}$.

3) Fibroblastic cells: On about the tenth day after the start of primary cell culture, the first cells to grow out from blocks were of this type (Fig. 1C). One month later, they were replaced by large cells bearing many processes and vacuoles, round cells with radial intracellular structures and the fourth type of cells (vide infra).

4) Blood cell-like cells: Small cells, measuring about $100 \mu \mathrm{m}$ in maximum diameter, with neither pigments nor processes, appeared as undifferentiated cells. These cells formed visible white masses by their proliferation into solid groups (Fig. 1D). In some cases, the central parts of the cell group became necrotic and eventually replaced by new cells growing from the outside. Cells growing on the surface of the foci were flattened, whereas those located toward the center of the foci were approximately conical in shape, although they varied in shape according to the density of the cells. The electron-microscopical profile of this type of cell is shown in Fig. 2. The cell surface and the nuclear membrane were irregularly wrinkled. The nucleus was very large, with high-density chromatin

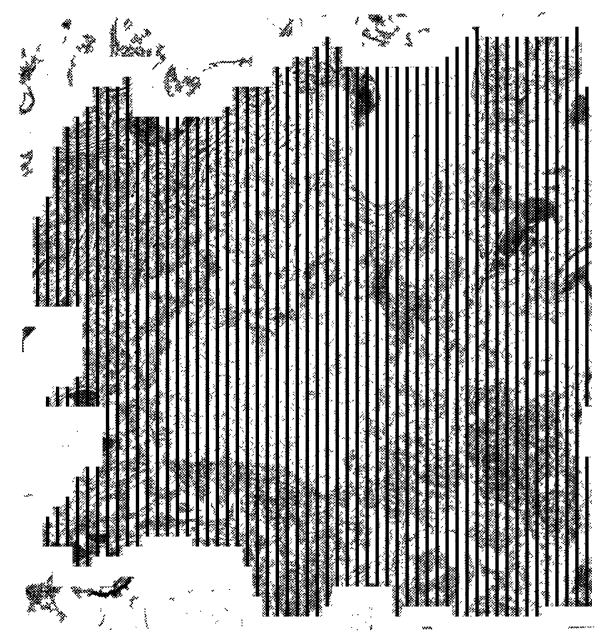

Fig. 2. Electron microscopy of blood celllike cell. C, chromatin; CM, cell membrane; ER, endoplasmic reticulum; Mit, mitochondria; N, nucleus; NcM, nuclear membrane.

in its center. In the cytoplasm, large amounts of ER (endoplasmic reticulum) and lysosomes were seen. The cristae mitochondriales were also irregular and occasionally destroyed. Although the cells of this type resembled blood cells, they appeared to be undifferentiated cells, with a rough cell surface, a large nucleus and few desmosomes.

Discussion. Although the cell lines have been established from some normal amphibian tissues, e.g. epidermis, kidney and liver, ${ }^{13)}$ only one has been reported from amphibian tumor, adenocarcinoma of Rana pipiens. ${ }^{16)}$ We have tried to 
establish a cell line from a tumor found in Xenopus laevis, by culturing the cells for a period over 2 years. We could distinguish four morphologically different cell types, i.e. melanophores, neuroid cells, fibroblastic cells and blood cell-like cells, among cell layers piled up in the cell sheet formed in culture dishes. The blood cell-like cells having features of undifferentiated cells, sometimes came together to form foci, without showing contact inhibition. The absence of cell contact inhibition is one of the most characteristic features of tumor cells. Electron microscopical observations also revealed in the blood cell-like cells, some characteristics of tumor cells, a large nucleus, breakage of the nuclear membrane and the irregularly wrinkled cell membrane (Fig. 2).

For the melanophore, a melanin-containing cell, there are some types derived from the tadpole of Rana.9) Melanophores cultured for a long time retained all the characteristics of normal, non-tumorous cells. Melanophores observed in our study showed also contact inhibition in the culture system, although they were sometimes stratified, even up to seven cell layers. In order to characterize and establish tumor cell lines, it will be necessary to clone each cell type and to carry out further studies using electron microscopy and histochemistry.

Acknowledgements. We are grateful to Drs. K. Sekiya and H. Watanabe of the University of Niigata for helpful suggestions. This work was supported in part by a Grant-in-Aid for Cancer Research from the Ministry of Education, Science and Culture of Japan.

\section{References}

1) Asashima, M. et al.: Cancer Research, 42, 3741-3746 (1982).

2) Asashima, M. et al.: ibid., 45, 1198-1205 (1985).

3) Asashima, M. et al.: Proc. Japan Acad., 62B, 83-86 (1986).

4) Ball, M., and L. N. Ruben: Exp. Cell Res., 43, 694-698 (1966).

5) DiBerardino, M. A., and T. J. King: Develop. Biol., 11, 217-242 (1965).

6) Harshbarger, J. C., A. M. Charles, and P. M. Spero: Phyletic Approaches to Cancer (eds. C. D. Dawe et al.). Japan Sci. Soc. Press, Tokyo, pp. 357-384 (1981).

7) Ito, S., and M. J. Karnovski: J. Cell Biol., 39, 168-169 (1968).

8) King, T. J., and M. A. DiBerardino: Ann. N.Y. Acad. Sci., 126, 115-126 (1965).

9) Kondo, H., and H. Ide: Exp. Cell Res., 149, 247-256 (1983).

10) Lucké, B.: Amer. J. Cancer, 20, 352-379 (1934).

11) Mizell, M.: Biology of Amphibian Tumors (ed. M. Mizell). New York, SpringerVerlag, pp. 1-25 (1969).

12) Oinuma, T., Seki, M., and M. Asashima: Proc. Japan Acad., 60B, 265-268 (1984).

13) Rafferty, K. A., Jr.: Biology of Amphibian Tumors (ed. M. Mizell). New York, Springer-Verlag, pp. 52-81 (1969).

14) - Physiology of Amphibia. vol. III (ed. B. Lofts). Academic Press, New York, pp. 111-162 (1976).

15) Schlumberger, H. G., and B. Lucké: Cancer Research, 8, 657-753 (1948).

16) Tweedell, K. S., and D. C. Williams: J. Cell Sci., 22, 385-395 (1976). 